\title{
Predicting the Drivers of the Intention to Use Mobile Learning in South Korea
}

\author{
https://doi.org/10.3991/ijim.v12i1.7688 \\ Hyo-Jung Kim( $\left.{ }^{\varpi}\right)$, Jong-Youn Rha \\ Seoul National University, Seoul, Republic of Korea \\ hyojungkimesnu.ac.kr
}

\begin{abstract}
This study empirically analyzed a survey conducted on South Korean undergraduate students to determine the factors that influence their decision to adopt mobile learning. The consumer typology approach was applied based on their mobile technology readiness, and identified three distinct consumer groups: critical adopters, pro-technology, and ambivalent. Critical adopters were the largest of the three groups, indicating that a significant portion of university students in South Korea might be critical adopters of mobile learning. Compatibility and observability positively influenced the intention to use mobile learning in all consumer groups. In the critical adopter and ambivalent groups, mobile learning resistance had the greatest effect on the intention to use mobile learning, while in the pro-technology group mobile learning selfefficacy had the greatest effect on this intention. Results identified significant differences across consumer groups in the antecedents and consequences of the intention to use mobile learning.
\end{abstract}

Keywords-Mobile learning, Technology readiness, Innovation characteristics, Innovation resistance, Status quo bias

\section{$1 \quad$ Introduction}

Widespread ownership of mobile devices and the increasing availability of wireless services have changed the landscape of higher education [1]. In general, mobile devices have been well-received as an educational tool due to nearly negating the limitations of place and time and providing a learner-centered educational environment [2]. Various mobile-based learning content has recently been developed, and researchers are actively studying teaching methods that utilize such content. However, there is relatively little practical interest in or utilization of mobile learning because, currently, the primary purpose of a mobile device is not instructional [3]; rather, people use mobile devices for communication and other, primarily hedonic purposes, such as listening to music, surfing the internet, or playing games [4], [5]. Furthermore, mobile devices such as smartphones typically have the disadvantages of featuring small screens, difficult text input, and limited storage, all of which contributes to individuals refusing or delaying the adoption of such devices as learning tools in a learning environment [6]. 
Most previous studies on mobile learning have used an adoption paradigm based on either the technology acceptance model or innovation diffusion theory. While these studies provide valuable baseline data for examining the acceptance of or satisfaction with mobile learning, they provide only limited clues as to why the acceptance of mobile learning is refused or delayed [7], [8].

New technologies are associated with uncertainty and risk, so it is not viable for all consumers to embrace them equally fast or well [9], [10]. Mobile learning is a method that uses and combines multiple new technologies, such as online networking, mobile content, and mobile devices; such a method provides a higher level of uncertainty and risk in individuals' perceptions, which may lead them to refuse or delay the acceptance of mobile learning.

This study investigates the phenomenon of delaying or refusing the acceptance of mobile learning based on technology readiness, an index that shows an individual's propensity to accept and use new technology to achieve a certain goal. An individual's intention to accept mobile learning may vary according to the perceived benefits and costs, but the factors that affect this acceptance may also vary according to the individual's perception of technology readiness in a mobile environment. Therefore, this study examines individuals' technology readiness in a mobile environment and creates a typology of consumers, thereby identifying the factors that affect the intention of using mobile learning according to consumer type. These factors are examined in terms of a model of innovation resistance (MIR) and innovation characteristics based in innovation diffusion theory (IDT); moreover, we determine the impact of personality traits such as self-efficacy or status quo bias on the intention to use mobile learning. Specifically, the present study poses these three research questions:

RQ1: What consumer groups can be identified according to technology readiness?

RQ2: How do the consumer groups differ in terms of innovation characteristics, personal characteristics, and outcome of the intention to use mobile learning?

RQ3: What factors affect consumers' intention to use mobile learning?

\section{Literature review}

\subsection{Technology readiness}

The drastically fast development of new technology has led to the phenomenon of consumers who cannot or refuse to accept such technology [11]. To accurately predict consumer behavior in such an environment, it is necessary to determine whether individuals are ready to accept new technology [12]. To this end, Parasuraman [13] developed the technology readiness index, based on groundwork by Mick and Fournier [14]. Technology readiness refers to an individual's propensity to accept and use new technology in order to achieve their goal at home or work, and it is categorized according to four dimensions. First, optimism indicates a positive attitude toward technology and the belief that the technology will increase control, flexibility, and efficiency in an individual's life. Second, innovativeness indicates the propensity of an individual to become an early adopter of or leader in technology and opinions. Third, 
discomfort indicates the perception that technology cannot be controlled by an individual and the feeling of being overwhelmed by technology. Fourth, insecurity indicates doubts about technology. Of these four dimensions, optimism and innovativeness are positive factors that increase technology readiness, whereas discomfort and insecurity are negative factors that suppress technology readiness [13].

Not all consumers are equally ready to embrace specific technology [10], as new technology is associated with uncertainty and risk. Individuals with high technology readiness tend to accept a high level of risk and uncertainty when dealing with new technology [15]. On the other hand, individuals with low technology readiness may feel uncomfortable or frustrated when using a new technology despite its multiple apparent benefits, such as saving time or improving work efficiency [13], [16]. Some individuals may feel anxiety over accepting new technology, or they may experience technophobia due to a pessimistic view of technology [10]. Therefore, an individual's technology readiness can be used as the basis for understanding their intention to accept or delay accepting new technology [12], [16].

\subsection{Innovation diffusion theory}

Innovation diffusion theory explains the decision-making process by focusing on the characteristics that affect innovation adoption. It has been used in various fields, such as education, sociology, communication, and information technology, to determine an individual's intention or level of acceptance of innovation. In this theory, innovation is defined as "an idea, practice, or object that is perceived as new by an individual or another unit of adoption." Diffusion is defined as "the process by which an innovation is communicated through certain channels over time among the members of a social system" [9].

Innovation diffusion theory comprises five innovation characteristics: relative advantage, compatibility, complexity, observability, and trialability. Relative advantage is defined as the degree to which an innovation is considered better than previous ideas or products. Relative advantage has been found to be one of the important predictors of the adoption of an innovation [9]. In previous studies, relative advantage turned out to have a positive effect on innovation adoption [16]. Previous studies on $\mathrm{m}$-learning have also shown that relative advantage has a positive effect on intention to adopt m-learning [17], [18]. Compatibility is defined as the degree to which an innovation is perceived as consistent with the values and needs of potential adopters [9]. Individuals tend to positively perceive technologies that are similar to their previous experiences. Therefore, Higher compatibility has a positive effect on the perceived ease of use and perceived usefulness of a technology, as well as on the behavioral intention to accept technology [18]. Complexity is perceived when an individual has difficulty understanding a certain innovation or using a certain technology, and it, too, has a significant effect on technology adoption and diffusion [9]. Previous studies have claimed that complexity is an impediment to innovation acceptance, and thus has a negative effect on the intention to use new technology [9]. Observability refers to the visibility of the outcome of innovation acceptance in other people. Observability turned out to have a positive effect on individual attitudes or behavioral intention 
related to technology use [9], [19]; if an individual regularly observes the use of a specific technology, they tend to consider the technology easier and more useful [20]. Trialability is defined as the degree to which innovations can be tested on a limited basis [9]. Trialability was found to have a positive effect on the use of certain systems or technologies [19]. Consumers who perceived a certain system or technology as having high trialability had an easier time using that system and considered it more useful [21]. Furthermore, studies on e-learning have also found that trialability has a positive effect not only on the perceived ease of use of e-learning, but also on the intention to accept e-learning [18].

\subsection{Intention to use mobile learning}

The prospect of mobile learning has been receiving attention in higher education, as it has little limitation when it comes to time and space, and it can therefore expand the scope of opportunities in education [2]. Mobile learning can provide access to overseas educational content, enabling interaction between individuals that cannot easily communicate face to face, which is thought to enhance the efficiency of education [22]. Unlike conventional learning methods that are limited by space and time, mobile learning is available for use anytime and anywhere, while also enhancing individual learning efficiency on the move [23]. Moreover, mobile learning enables the reuse of educational resources and allows individually optimized learning [24].

Despite the diverse benefits of mobile learning, some studies have claimed that students do not prefer mobile learning because of the limitations of mobile devices [5]. In prior studies, identified reasons for students not accepting mobile learning are as follows. First, there are the limitations of the device itself, such as the small screen and limited memory [3]. Second, there are psychological limitations. As students mostly use mobile devices for hedonic purposes such as texting friends or listening to music, rather than instructional purposes, this may cause psychological resistance to accepting mobile devices as learning tools [5], [25]. Third, there are pedagogical limitations, as students' level of concentration might be reduced by using a mobile device in class, thereby exerting an overall negative effect on education.

While mobile learning is a useful tool in the ICT environment, it has both benefits and disadvantages. To use mobile learning as a method that overcomes the limitations of traditional education methods and improves educational efficiency, it is necessary to precisely determine these disadvantages and find ways to alleviate or remove them [3].

\subsection{Self-efficacy}

Self-efficacy is an individual's belief in their ability to successfully perform the behaviors required to produce certain outcomes [26]. Self-efficacy as an index may measure an individual's self-confidence in utilizing innovation [27], and it is an important factor that affects high technology adoption [28]. Self-efficacy in a learning environment may positively affect a learner's motivation, concentration, and learning effectiveness. Students with a higher level of self-efficacy tend to have more confi- 
dence in learning situations [29]. Moreover, self-efficacy has been found to have a positive effect on the intention to use web-based learning, and instructors with a high level of self-efficacy related to technology tend to prefer conducting class using technology [29] [30].

\subsection{Innovation resistance}

Consumers' innovation resistance is merely a factor that affects decision-making when it comes to the non-adoption of innovation or a new technology, but it does not indicate non-adoption itself [31]. When consumers face change, they feel instability, which causes resistance to the change. As such, consumer resistance is a natural mental state in the process of innovation acceptance. Innovation resistance is, in essence, the attitude of non-adoption toward innovation, and is used to describe how individuals may accept innovation at different levels [31]. Individuals who tend to be resistant to change refrain from collecting data about new products due to the stress caused by first encountering new products [32], and they are reluctant to invest time or effort into adjusting to a new technology or product [33]. In previous research, resistance turned out to have a negative effect on accepting new technology and on IT usage behavior [34].

\subsection{Status quo bias}

Status quo bias is "doing nothing or maintaining one's current or previous decision" rather than changing it [35]. According to the status quo bias theory, individuals tend to weight loss more highly than gain when evaluating the outcome of a certain behavior, thereby producing status quo bias. Essentially, other conditions being equal, individuals possess the psychological attribute of sticking with conventional ways and resisting change [36]. Individuals with stronger status quo bias are more passively resistant to innovation [37].

\section{$3 \quad$ Research methodology}

\subsection{Measurement}

In this study, we adopted constructs from prior studies to fit the mobile learning context. Thirty-five questionnaire items were measured using multiple items on a 5 point Likert scale, ranging from " $1=$ strongly disagree" to " $5=$ strongly agree". The items used in the questionnaire are listed in Appendix A.

\subsection{Data collection and sample characteristics}

The data were collected using an online survey. The questionnaire was administered to a panel of online research companies from March 24 to 28, 2016. The participant recruitment and data collection were conducted by Embrain 
(www.embrain.com), a professional online survey company. The sample used in this study consists of South Korean undergraduate students. Korean universities are suitable for the purposes of this study because e-learning and mobile learning are wellestablished, most Korean universities have e-learning and mobile learning systems, and online learning courses are encouraged. Before the questionnaire, the definition of mobile learning in this study was presented as a "learning style via the Internet or network using personal mobile devices, such as tablets, smartphones, and notebooks to obtain learning materials through mobile apps, social interactions, and online educational hubs" [5]. To enhance representativeness, quota sampling was applied. A total of 580 completed responses were used. Table 1 shows the general characteristics of the sample.

Table 1. Respondents' characteristics $(n=580)$

\begin{tabular}{|c|c|c|}
\hline \multicolumn{2}{|c|}{ Construct } & Number (\%) \\
\hline \multirow{2}{*}{ Gender } & Male & $283(48.8 \%)$ \\
\cline { 2 - 3 } & Female & $297(51.2 \%)$ \\
\hline \multirow{3}{*}{$\begin{array}{c}\text { Age } \\
(M=22.47)\end{array}$} & $20-22$ & $314(54.1 \%)$ \\
\cline { 2 - 3 } & $23-25$ & $215(37.1 \%)$ \\
\cline { 2 - 3 } & $26-28$ & $51(8.8 \%)$ \\
\hline \multirow{3}{*}{$\begin{array}{c}\text { Smart device ownership } \\
(\text { multiple choice) }\end{array}$} & Smartphone & $580(100 \%)$ \\
\cline { 2 - 3 } & Desktop & $430(74.1 \%)$ \\
\cline { 2 - 3 } & Notebook & $487(84 \%)$ \\
\cline { 2 - 3 } & Tablet PC & $170(29.3 \%)$ \\
\hline
\end{tabular}

\subsection{Data analysis}

SPSS 19.0 was used for descriptive statistics, factor analysis, internal consistency reliabilities (Cronbach's $\alpha$ ), k-means cluster analysis, chi-squared test, ANOVA, and multiple regression analysis. The multiple regression analysis identified the factors that influence consumers' intention to use mobile learning.

\section{$4 \quad$ Results}

\subsection{Reliability and validity of technology readiness}

Factor analysis with varimax rotation was used to assess the discriminant and convergent validity of technology readiness. The questionnaire comprised 12 questions related to optimism, innovation, discomfort, and insecurity; however, one of the items used to measure discomfort was eliminated because its standardized factor loadings were not statistically significant, so 11 items were used in the final analysis. The Kaiser-Meyer-Olkin measure verified the sampling adequacy for the analysis, and Bartlett's test indicated that the correlations between items were sufficient for principal component analysis $\left(\mathrm{KMO}=.743 ; x^{2}=1995.156 ; p<.001\right)$. All standardized factor 
loadings were statistically significant and greater than 0.60 , which exceeded the acceptable benchmark. Reliability analyses confirmed that four factors had psychometric properties. For internal consistency reliabilities (Cronbach's $\alpha$ ) that exceeded .07, measurement reliability was verified [38]. The results are shown in Table 2.

Table 2. Factor analysis results

\begin{tabular}{|c|c|c|c|c|c|}
\hline \multirow{2}{*}{\multicolumn{2}{|c|}{ Construct }} & \multicolumn{4}{|c|}{ Factor Loading } \\
\hline & & \multirow{2}{*}{$\begin{array}{c}1 \\
.855\end{array}$} & \multirow{2}{*}{$\begin{array}{c}2 \\
-.006\end{array}$} & \multirow{2}{*}{$\begin{array}{c}3 \\
.133 \\
\end{array}$} & \multirow{2}{*}{$\begin{array}{c}4 \\
-.106\end{array}$} \\
\hline \multirow{3}{*}{ Optimism } & 1 & & & & \\
\hline & 2 & .887 & .028 & .061 & -.097 \\
\hline & 3 & .815 & -.129 & .077 & .024 \\
\hline \multirow{3}{*}{ Innovativeness } & 1 & .055 & -.047 & .849 & .089 \\
\hline & 2 & .015 & -.013 & .854 & -.013 \\
\hline & 3 & .214 & .061 & .710 & -.142 \\
\hline \multirow{2}{*}{ Discomfort } & 1 & -.121 & .188 & -.153 & .840 \\
\hline & 2 & -.038 & .268 & .106 & .823 \\
\hline \multirow{3}{*}{ Insecurity } & 1 & -.068 & .812 & .133 & .068 \\
\hline & 2 & -.029 & .824 & -.101 & .173 \\
\hline & 3 & -.006 & .777 & -.043 & .262 \\
\hline \multicolumn{2}{|c|}{ Cronbach's $\alpha$} & .825 & .748 & .712 & .764 \\
\hline \multicolumn{2}{|c|}{ Eigenvalue } & 2.253 & 2.072 & 2.047 & 1.535 \\
\hline \multicolumn{2}{|c|}{$\%$ of variance after rotation } & 20.484 & 39.321 & 57.929 & 71.886 \\
\hline
\end{tabular}

\subsection{Consumer typology}

k-means cluster analysis was conducted to classify consumers according to technology readiness. A three-cluster solution was chosen as the best fit. To confirm the distinctive characteristics of each cluster, ANOVA and Scheffé's post hoc test were conducted. The three consumer clusters were classified and labeled as follows to reflect their characteristics: cluster 1 was labeled "critical adopter" $(n=290)$, cluster 2 "pro-technology" $(\mathrm{n}=163)$, and cluster 3 "ambivalent" $(\mathrm{n}=127)$. The results are presented in Table 3.

Table 4 summarizes the demographic profiles and characteristics of each cluster. The results of the chi-square test indicate significant gender differences across the three clusters: there was high proportion of males in the pro-technology group, and a high proportion of females in the critical adopter group.

\subsection{Differences in antecedent and outcome variables by consumer group}

Table 5 shows the difference in antecedent and outcome variables by consumer group. The mean scores for relative advantage, compatibility, mobile learning resistance, status quo bias, and intention to use mobile learning was significantly higher in the ambivalent group than in the other two. The mean scores for trialability and mobile learning self-efficacy were significantly higher in the pro-technology group 
than in the other two. The mean scores for relative advantage, compatibility, observability, trialability, mobile learning self-efficacy and intention to use mobile learning were significantly lower in the critical adopter group than in the other two. The mean scores for complexity, mobile learning resistance, and status quo bias were significantly lower in the pro-technology group than in the other two.

Table 3. k-means cluster analysis results

\begin{tabular}{|c|c|c|c|c|c|}
\hline \multirow[b]{2}{*}{ Construct } & Cluster 1 & Cluster 2 & Cluster 3 & \multirow[b]{2}{*}{ Mean } & \multirow[b]{2}{*}{$F$} \\
\hline & $\begin{array}{c}\text { Critical adopter } \\
(n=290)\end{array}$ & $\begin{array}{c}\text { Pro technology } \\
(n=163)\end{array}$ & $\begin{array}{c}\text { Ambi-valent } \\
(n=127)\end{array}$ & & \\
\hline Optimism & $3.772 \mathrm{a}$ & $4.441 \mathrm{c}$ & $4.105 \mathrm{~b}$ & 4.028 & $78.839^{* * *}$ \\
\hline $\begin{array}{c}\text { Innovative- } \\
\text { ness }\end{array}$ & $2.740 \mathrm{a}$ & $3.725 \mathrm{~b}$ & $3.622 \mathrm{~b}$ & 3.206 & $186.851^{* * *}$ \\
\hline Discomfort & $2.741 \mathrm{~b}$ & $1.985 \mathrm{a}$ & $3.613 \mathrm{c}$ & 2.776 & $243.35^{* * *}$ \\
\hline Insecurity & $3.050 \mathrm{~b}$ & $2.462 \mathrm{a}$ & $3.991 \mathrm{c}$ & 3.090 & $195.228^{* * *}$ \\
\hline
\end{tabular}

Note: $\mathrm{a}, \mathrm{b}, \mathrm{c}=$ group difference by Scheffé's test; ${ }^{* * *} p<0.001$

Table 4. Characteristics by clusters.

\begin{tabular}{|c|c|c|c|c|c|}
\hline \multicolumn{2}{|c|}{ Construct } & $\begin{array}{c}\text { Critical adopter } \\
(\mathbf{n}=\mathbf{2 9 0})\end{array}$ & $\begin{array}{c}\text { Pro-technology } \\
(\mathbf{n}=\mathbf{1 6 3})\end{array}$ & $\begin{array}{c}\text { Ambivalent } \\
(\mathbf{n}=127)\end{array}$ & $\begin{array}{c}\text { Chi- } \\
\text { squared }\end{array}$ \\
\hline \multirow{2}{*}{ Gender } & Male & $124(42.8 \%)$ & $98(60.1 \%)$ & $61(48.0 \%)$ & \multirow{2}{*}{$12.630^{* *}$} \\
\cline { 2 - 5 } & Female & $166(57.2 \%)$ & $65(39.9 \%)$ & $66(52.0 \%)$ & \\
\hline \multirow{3}{*}{ Age } & $20-22$ & $171(59.0 \%)$ & $75(46.0 \%)$ & $68(53.5 \%)$ & \multirow{2}{*}{8.171} \\
\cline { 2 - 5 } & $23-25$ & $95(32.7 \%)$ & $74(45.4 \%)$ & $46(36.3 \%)$ & \\
\cline { 2 - 5 } & $26-28$ & $24(8.3 \%)$ & $14(8.6 \%)$ & $13(10.2 \%)$ & \\
\hline
\end{tabular}

Table 5. ANOVA results for antecedent variables by group

\begin{tabular}{|l|c|c|c|c|c|}
\hline \multicolumn{1}{|c|}{ Construct } & $\begin{array}{c}\text { Critical } \\
\text { adopter } \\
(\mathbf{n = 2 9 0 )}\end{array}$ & $\begin{array}{c}\text { Pro-technology } \\
(\mathbf{n = 1 6 3 )}\end{array}$ & $\begin{array}{c}\text { Ambivalent } \\
\text { (n= 127) }\end{array}$ & Mean & $\boldsymbol{F}$ \\
\hline Relative advantage (RA) & $3.860 \mathrm{a}$ & $3.946 \mathrm{ab}$ & $4.086 \mathrm{~b}$ & 3.964 & $4.101^{*}$ \\
\hline Compatibility (CB) & $3.601 \mathrm{a}$ & $3.671 \mathrm{a}$ & $3.948 \mathrm{~b}$ & 3.740 & $6.209^{* *}$ \\
\hline Complexity (CP) & $3.001 \mathrm{~b}$ & $2.278 \mathrm{a}$ & $3.332 \mathrm{~b}$ & 2.870 & $17.513^{* * *}$ \\
\hline Observability (OB) & $3.655 \mathrm{a}$ & $3.730 \mathrm{a}$ & $3.960 \mathrm{~b}$ & 3.781 & $4.171^{*}$ \\
\hline Trialability (TR) & $2.621 \mathrm{a}$ & $2.984 \mathrm{~b}$ & $2.703 \mathrm{ab}$ & 2.769 & $4.308^{*}$ \\
\hline $\begin{array}{l}\text { Mobile learning } \\
\text { self-efficacy (SE) }\end{array}$ & $3.082 \mathrm{a}$ & $3.838 \mathrm{c}$ & $3.150 \mathrm{~b}$ & 3.356 & $44.069^{* * *}$ \\
\hline $\begin{array}{l}\text { Mobile learning } \\
\text { Resistance (RE) }\end{array}$ & $2.971 \mathrm{~b}$ & $2.670 \mathrm{a}$ & $3.190 \mathrm{c}$ & 2.943 & $11.613^{* * *}$ \\
\hline Status quo bias (SQ) & $3.009 \mathrm{~b}$ & $2.887 \mathrm{a}$ & $3.323 \mathrm{c}$ & 3.073 & $8.549^{* * *}$ \\
\hline $\begin{array}{l}\text { Intention to use } \\
\text { mobile learning (IM) }\end{array}$ & $2.941 \mathrm{a}$ & $3.318 \mathrm{~b}$ & $3.202 \mathrm{~b}$ & 3.097 & $10.588^{* * *}$ \\
\hline
\end{tabular}

Note: $\mathrm{a}<\mathrm{b}<\mathrm{c}=$ group difference by Scheffé's test; ${ }^{*} p<0.05,{ }^{*} p<0.01,{ }^{* * *} p<0.001$ 


\subsection{Correlation coefficient of variables}

The correlation of coefficients are displayed in Table 6. The correlation coefficients between all the variables were less than 0.70 that is the recommended threshold, so there are no severe multicollinearity problems [39].

Table 6. Correlations between all the variables

\begin{tabular}{|c|c|c|c|c|c|c|c|c|c|}
\hline Const. & $\mathbf{( 1 )}$ & $\mathbf{( 2 )}$ & $\mathbf{( 3 )}$ & $\mathbf{( 4 )}$ & $\mathbf{( 5 )}$ & $\mathbf{( 6 )}$ & $\mathbf{( 7 )}$ & $\mathbf{( 8 )}$ & (9) \\
\hline$(1) \mathrm{RA}$ & 1 & & & & & & & & \\
\hline$(2) \mathrm{CB}$ & $.624^{* *}$ & 1 & & & & & & & \\
\hline$(3) \mathrm{CP}$ & -.030 & -.052 & 1 & & & & & & \\
\hline$(4) \mathrm{OB}$ & $.377^{* *}$ & $.322^{* *}$ & -.077 & 1 & & & & & \\
\hline$(5) \mathrm{TR}$ & $.382^{* *}$ & $.317^{* *}$ & -.030 & $.648^{* *}$ & 1 & & & & \\
\hline$(6) \mathrm{SE}$ & $.286^{* *}$ & $.245^{* *}$ & $-.311^{* *}$ & $.358^{* *}$ & $.358^{* *}$ & 1 & & & \\
\hline$(7) \mathrm{RE}$ & $-.301^{* *}$ & $-.416^{* *}$ & $.386^{* *}$ & $-.128^{* *}$ & $-.195^{* *}$ & $-.209^{* *}$ & 1 & & \\
\hline$(8) \mathrm{SQ}$ & -.006 & $-.118^{* *}$ & $.323^{* *}$ & .055 & .042 & -.030 & $.429^{* *}$ & 1 & \\
\hline$(9) \mathrm{IM}$ & $.524 * *$ & $.550^{* *}$ & $-.143^{* *}$ & $.443^{* *}$ & $.510^{* *}$ & $.344^{* *}$ & $-.470^{* *}$ & $-.116^{* *}$ & 1 \\
\hline
\end{tabular}

Note: ${ }^{* *} p<0.01$.

\subsection{Factors that influence intention to use mobile learning}

Table 7 shows the results of multiple regression analysis of each group. The models for the critical adopter group $\left(\mathrm{R}^{2}=.392, \mathrm{~F}=27.599, p<.001\right)$, pro-technology group $\left(\mathrm{R}^{2}=.637, \mathrm{~F}=41.628, p<.001\right)$, and ambivalent group $\left(\mathrm{R}^{2}=.482, \mathrm{~F}=17.718\right.$, $p<.001)$ were significant and showed acceptable goodness of fit. Mobile learning resistance $(\beta=-.313)$ had the strongest impact on intention to use mobile learning in the critical adopter group, followed by observability $(\beta=.282)$, complexity $(\beta=-.279)$, compatibility $(\beta=.151)$, and relative advantage $(\beta=.122)$. Mobile learning selfefficacy $(\beta=.215)$ had the strongest impact on intention to use mobile learning in the pro-technology group, followed by trialability $(\beta=.203)$, relative advantage $(\beta=.185)$, compatibility $(\beta=.174)$, and observability $(\beta=.138)$. Mobile learning resistance $(\beta=-$ $.359)$ had the strongest impact on intention to use mobile learning in the ambivalent group, followed by observability $(\beta=.257)$, relative advantage $(\beta=.224)$, compatibility $(\beta=.220)$, complexity $(\beta=-.184)$, and status quo bias $(\beta=-.118)$. Three multiple regression models were formulated and tested for the dependent variable of intention to use mobile learning. To evaluate the strength of the significant effects, Cohen's 2 was calculated. According to this measure, the three consumer groups of the multiple regression model showed a "large" size effect: the critical adopter group (.644), the pro-technology group (1.754), and the ambivalent group (.930). 
Table 7. Regression analysis of intention to use mobile learning

\begin{tabular}{|l|c|c|c|c|c|c|}
\hline \multirow{2}{*}{ Construct } & \multicolumn{2}{|c|}{$\begin{array}{c}\text { Critical adopter } \\
(\mathbf{n = 2 9 0 )}\end{array}$} & \multicolumn{2}{c|}{$\begin{array}{c}\text { Pro-technology } \\
(\mathbf{n}=\mathbf{1 6 3})\end{array}$} & \multicolumn{2}{c|}{$\begin{array}{c}\text { Ambivalent } \\
(\mathbf{n}=\mathbf{1 2 7})\end{array}$} \\
\cline { 2 - 7 } & $\boldsymbol{\beta}$ & $\boldsymbol{p}$ & $\boldsymbol{\beta}$ & $\boldsymbol{p}$ & $\boldsymbol{\beta}$ & $\boldsymbol{p}$ \\
\hline Relative advantage & $.122^{*}$ & .033 & $.185^{* *}$ & .009 & $.224^{*}$ & .017 \\
\hline Compatibility & $.151^{*}$ & .012 & $.174^{*}$ & .023 & $.220^{* *}$ & .009 \\
\hline Complexity & $-.279^{*}$ & .043 & -.003 & .953 & $-.184^{*}$ & .048 \\
\hline Observability & $.282^{* * *}$ & .000 & $.138^{*}$ & .036 & $.257^{* *}$ & .006 \\
\hline Trialability & .010 & .880 & $.203^{* *}$ & .001 & .019 & .830 \\
\hline $\begin{array}{l}\text { Mobile learning } \\
\text { self-efficacy }\end{array}$ & .045 & .404 & $.215^{*}$ & .044 & $.184^{*}$ & .018 \\
\hline $\begin{array}{l}\text { Mobile learning } \\
\text { resistance }\end{array}$ & $-.313^{* * *}$ & .000 & -.109 & .179 & $-.359^{*}$ & .016 \\
\hline Status quo bias & -.104 & .097 & -.023 & .476 & $-.118^{*}$ & .013 \\
\hline$F$ & \multicolumn{2}{|c|}{$27.599^{* * *}$} & $41.628^{* * *}$ & \multicolumn{2}{c|}{$17.718^{* * *}$} \\
\hline$R^{2}$ & \multicolumn{2}{|c|}{.392} & \multicolumn{2}{c|}{.637} & \multicolumn{2}{c|}{.482} \\
\hline Cohen's $f^{2}$ & \multicolumn{2}{|c|}{.644} & \multicolumn{2}{c}{1.754} & \multicolumn{2}{c}{.930} \\
\hline
\end{tabular}

Note: $* p<0.05, * * p<0.01, * * * p<0.001$.

Note: Cohen's f2 was calculated as $\mathrm{f} 2=\mathrm{R} 2 /(1-\mathrm{R} 2)$. Cohen [40] suggests that "small", "medium", and "large" effect sizes correspond to $.02, .15$, and .35 , respectively.

\section{$5 \quad$ Discussion and conclusion}

The present study identified three distinct consumer groups according to their technology readiness: critical adopters, pro-technology, and ambivalent. Critical adopters were the largest of the three groups, meaning that a significant portion of university students in South Korea may be critical adopters of mobile learning.

This indicates that, even if students perceive the benefits of mobile learning, they may not adopt it unconditionally. This is consistent with previous research where most consumers evaluate an innovation through subjective assessment and do not always line up as innovators in all situations [31], [33], [37], [43].

Mobile learning enables space-independent personalized learning and improves learning efficiency, whereas it is difficult for individuals to self-police when it comes to learning, and there are practical limitations to mobile devices such as difficult text input and information delivery due to small screens [4], [23]. Despite the varied benefits of mobile learning, its costs may cause students to delay or refuse adopting mobile learning. Therefore, it is necessary to identify downsides of mobile learning and make efforts to alleviate them.

In addition, mobile learning may be a useful tool not only for students, but also teachers, increasing learning efficiency by overcoming the limitations of conventional learning methods [41]. For mobile learning to be a reliably efficient educational tool for students, it is necessary to precisely determine its benefits. Moreover, while it is important to produce various mobile learning content, it is also necessary to develop content based on the benefits of mobile learning perceived by students. 
Compatibility increases intention to use mobile learning in all consumer groups, indicating that mobile learning is more readily adopted when it is consistent with conventional learning methods or individuals' values. As reported in previous research, if an innovation is perceived as consistent with their experiences and requirements, it enhances consumers' intention to use the innovation [9], [18], [31]. Therefore, this study supports previous research on innovation diffusion theory.

If new technology is incompatible with their values or life, consumers may suffer greater anxiety or experience technophobia [10], [42]. Therefore, to employ mobile learning as a tool that is consistent with students' requirements and values, it is necessary to understand those values and requirements before expanding mobile learning content and subjects.

Observability is the visibility of the outcome of innovation acceptance to other people [9], and this study has found that it had positive effects on the intention to use mobile learning in all consumer groups. This result is in line with the results of previous studies that have found that individuals' intention to use mobile learning increases as more people around them use mobile learning [4], [17]. Once they observe how people around them accept and use a certain innovation, they accept the fact that the utility of the innovation has been proved, which reduces their uncertainty in the innovation and the risk they associate with it [20]. Therefore, regular publicity of mobile learning is needed in order for students to perceive it as a useful learning tool. Furthermore, teachers who use mobile learning should be able to clearly convey the benefits of mobile learning to students.

In the critical adopter and ambivalent groups, mobile learning resistance had the greatest effect on the intention to use mobile learning. The two groups both had the highest optimism and insecurity in mobile technology readiness. These results imply that positive and negative ideas about mobile technology may not be the most important factor that affects intention to use mobile learning in these two groups. The most important factor influencing this intention could be the degree of resistance that is the trait of individuals. These results expand on previous research by Ram [31], that resistance can be a predictor of adoption-related behaviors and barriers of innovation diffusion. Resistance may change depending on the situation, and its level may differ according to the characteristics of innovation or technology as well [31], [34]. Thus, it is necessary to identify the existence and degree of resistance to mobile learning; also the causes of resistance and factors that might reduce resistance could be explored.

Mobile learning self-efficacy had the greatest effect on the intention to use mobile learning in the pro-technology group, which had higher innovativeness and optimism toward mobile technology than other consumer groups. Individuals with higher innovativeness and optimism tend to have more positive views about using high-tech gadgets such as smartphones and smartwatches or related services. Furthermore, they tend to be less resistant to new technology and perceive fewer technology-related risk factors than others [18], [43]. This is why the pro-technology group showed higher mobile learning self-efficacy than other groups. However, in the critical adopter and ambivalent groups, mobile learning self-efficacy did not have a significant effect on the intention to use mobile learning, which may be because both groups had higher negative perceptions of mobile technology, such as discomfort and insecurity. There- 
fore, future research should determine how positive factors of technology readiness (optimism and innovativeness) and negative factors of technology readiness (discomfort and insecurity) are related to mobile learning self-efficacy.

Complexity was found to reduce the intention to use mobile learning in the critical adopter and ambivalent groups, but it had no effect in the pro-technology group. These results imply that the pro-technology group has high mobile learning self-efficacy and perceives low complexity in mobile learning than other consumer groups. Complexity is known to have a negative effect on new technology acceptance or service satisfaction [17], [18]. Accordingly, future research should specifically examine in which part of mobile learning the critical adopter and ambivalent groups perceive complexity, accompanied by efforts to reduce such complexity.

Status quo bias was found to reduce the intention to use mobile learning only in the ambivalent group, which highly perceives optimism, innovativeness, discomfort, and insecurity in mobile technology. Status quo bias appears in individuals who focus more on losses than benefits in evaluating the results of certain behaviors [33]. Individuals do not evaluate innovations based on scientific facts, but based on elements such as their values or personality [9]. Therefore, to increase the intention to use mobile learning in the ambivalent group, it is necessary to make efforts to reduce the current mobile learning costs. Moreover, the fact that individual values of new technology or its individual characteristics may affect the use of such new technology should not be overlooked [44]. Thus, to promote understanding about acceptance or diffusion of mobile learning, it is necessary to examine the effects of an individual's values or personal characteristics on mobile learning.

An important characteristic of our study is the attempt to explore the intention to employ mobile learning based on the consumer typology of technology readiness. Most prior studies only focused on the cost and benefits of mobile learning and predictors of mobile learning adoption [17], [20], [22], [23]. Consumers' attitude and perception of mobile technology can potentially affect mobile learning adoption. Therefore, considering consumers' mobile technology readiness will enhance understanding of mobile learning adoption.

This study contributes to a broader understanding of diffusion of innovation model in two ways. First, our results contribute to understanding different innovationdecisions of consumers. According to diffusion of innovation model, the innovationdecision is based on cost-benefit analysis of innovation, but is highly subjective and varies among individuals. Therefore, consumers adopt innovations at different rates and different times [9], [18]. This study identifies three consumer groups, who possess different degrees of intention to use mobile learning and different predictors of innovation-decisions. These results are consistent with diffusion of innovation model that distinguishes the consumer groups based on their innovation-decisions.

Second, our research findings contribute to expanding previous understandings of antecedents of innovation diffusion. The results of our study reveal that not only perceived technology characteristics but also personal traits such as self-efficacy and resistance are determining factors in adopting mobile learning. These findings are consistent with innovation diffusion theory and support prior studies that applied innovation diffusion theory in mobile technology environments [9], [34], [43]. Even if 
benefits of mobile learning outweigh the costs, some consumers can delay or refuse to adopt mobile learning. Therefore, understanding of consumers' characteristics can play an important role in problem solving for failure of innovation diffusion.

This study was firstly limited in that mobile learning is based on smart devices such as smart phones, tablet PCs, and notebooks, which are easily portable, so mobile learning can have different advantages and disadvantages for different students depending on the smart device they use. Second, the intention to continuously use mobile learning depends on the characteristics of individual courses. However, this study examined the intention of continued use of mobile learning from a comprehensive viewpoint. Therefore, in future research, it is necessary to investigate the intention to accept and persistent in using mobile learning according to the specific characteristics of educational content.

\section{Appendix A.}

\begin{tabular}{|c|c|c|}
\hline Construct & Item & \\
\hline Optimism & $\begin{array}{l}\text { Mobile technology makes you more efficient in your work. } \\
\text { Mobile technology gives people more control over their lives. } \\
\text { Mobile technology gives you more freedom of mobility. }\end{array}$ & \multirow{4}{*}{ [13] } \\
\hline $\begin{array}{l}\text { Innovative } \\
\text {-ness }\end{array}$ & $\begin{array}{l}\text { You keep up with the latest mobile technology development in your } \\
\text { area of interest. } \\
\text { You can usually figure out new high-tech products and services without } \\
\text { help from others. } \\
\text { You enjoy the challenge of figuring out high-tech mobile gadgets. }\end{array}$ & \\
\hline Discomfort & $\begin{array}{l}\text { When I get technical support from a provider of a high-tech product or } \\
\text { service, I sometimes feel as if I am being taken advantage of by some- } \\
\text { one who knows more than I do. } \\
\text { It is embarrassing when I have trouble with a high-tech mobile gadget } \\
\text { while people are watching. }\end{array}$ & \\
\hline Insecurity & $\begin{array}{l}\text { I worry that information sent over the mobile will be seen by other } \\
\text { people. } \\
\text { I don't feel confident doing business with a place that can only be } \\
\text { reached by mobile. } \\
\text { If I send information over a mobile, I can never be sure it really gets to } \\
\text { the right place. }\end{array}$ & \\
\hline $\begin{array}{l}\text { Relative ad- } \\
\text { vantage }\end{array}$ & $\begin{array}{l}\text { Mobile learning is relatively faster than existing learning methods. } \\
\text { Mobile learning is relatively more convenient than existing learning } \\
\text { methods. } \\
\text { Mobile learning is relatively more efficient than existing learning meth- } \\
\text { ods. }\end{array}$ & \multirow{3}{*}{$\begin{array}{c}{[9]} \\
{[45]}\end{array}$} \\
\hline Compatibility & $\begin{array}{l}\text { Mobile learning fits my lifestyle. } \\
\text { Mobile learning fits my learning style. }\end{array}$ & \\
\hline Complexity & $\begin{array}{l}\text { Mobile learning is complex and difficult. } \\
\text { Mobile learning is more difficult to familiarize oneself with than other } \\
\text { learning methods. } \\
\text { It is difficult to learn how to use services or devices for mobile learning. }\end{array}$ & \\
\hline
\end{tabular}




\begin{tabular}{|l|l|l|}
\hline Observability & $\begin{array}{l}\text { I can easily find students who are learning by mobile. } \\
\text { Many students in my school are engaging in mobile learning. } \\
\text { I often see people learning on the mobile. }\end{array}$ & $\begin{array}{l}\text { A variety of mobile learning applications have been developed. } \\
\text { I can easily find mobile learning content. } \\
\text { There is plenty of information available for mobile learning. }\end{array}$ \\
\hline $\begin{array}{l}\text { Mobile learn- } \\
\text { ing self- } \\
\text { efficacy }\end{array}$ & $\begin{array}{l}\text { I can manage my personal information when using mobile learning. } \\
\text { I can control how my personal information will be collected and used by } \\
\text { mobile learning providers. } \\
\text { I can take steps to protect my privacy when using mobile learning. }\end{array}$ & [46] \\
\hline $\begin{array}{l}\text { Mobile learn- } \\
\text { ing resistance }\end{array}$ & $\begin{array}{l}\text { I feel reluctant to use mobile learning. } \\
\text { I oppose the change of my existing learning method into mobile learning. }\end{array}$ & {$[8]$} \\
\hline $\begin{array}{l}\text { Status quo } \\
\text { bias }\end{array}$ & $\begin{array}{l}\text { I will continue using my existing learning method because it would be } \\
\text { Itressful to change. } \\
\text { what I have always done. } \\
\text { I will continue using my existing learning method even though I know it } \\
\text { is not the most effective way to do things. }\end{array}$ & {$[47]$} \\
\hline $\begin{array}{l}\text { Intention to } \\
\text { learning mobile }\end{array}$ & $\begin{array}{l}\text { I will use mobile learning. } \\
\text { I will encourage the use of mobile learning to other people. }\end{array}$ & {$[17]$} \\
\hline
\end{tabular}

\section{$7 \quad$ References}

[1] G. W. H. Tan, K. B. Ooi, L. Y. Leong and B. Lin, B, "Predicting the drivers of behavioral intention to use mobile learning: A hybrid SEM-Neural networks approach," Comput $\mathrm{Hu}-$ man Behav, Vol. 36, pp. 198-213, 2014. https://doi.org/10.1016/j.chb.2014.03.052

[2] M. Al-Emran, H. M. Elsherif and K. Shaalan, "Investigating attitudes towards the use of mobile learning in higher education," Comput. Human Behav., Vol. 56, pp. 93-102, 2016. https://doi.org/10.1016/j.chb.2015.11.033

[3] M. Hashemi et al., "What is mobile learning? Challenges and capabilities," Procedia Soc Behav Sci, Vol. 30, pp. 2477-2481, 2011. https://doi.org/10.1016/j.sbspro.2011.10.483

[4] J. Cheon et al., "An investigation of mobile learning readiness in higher education based on the theory of planned behavior," Compt Educ, Vol. 59(3), pp. 1054-1064, 2012. https://doi.org/10.1016/j.compedu.2012.04.015

[5] Y. S., Wang et al., "Investigating the determinants and age and gender differences in the acceptance of mobile learning," Br J Educ Technol, Vol. 40(1), pp. 92-118, 2009. http://dx.doi.org/10.1111/j.1467-8535.2007.00809.x

[6] D. Furió et al., "Mobile learning vs. traditional classroom lessons: a comparative study," J Comput Assist Learn, Vol. 31(3), pp. 189-201, 2015. https://doi.org/10.1111/jcal.12071

[7] K. F. Hashim et al., "Adult learners' intention to adopt mobile learning: A motivational perspective,” Br J Educ Technol, Vol. 46(2), pp. 381-390, 2015. https://doi.org/10.1111/ bjet. 12148

[8] H. W. Kim and A. Kankanhalli, "Investigating user resistance to information systems implementation: a status quo bias perspective," MIS Q, Vol. 33(3), pp. 567-582, 2009. http://www.jstor.org/stable/20650309, https://doi.org/10.2307/20650309

[9] E. M. Rogers, "Diffusion of innovations (3th ed.)," New York: Free Press, 2003. 
[10] H. R. Yen, H. R. "An attribute-based model of quality satisfaction for internet self-service technology,” Serv Ind J, Vol. 25(5), pp. 641-659, 2005. http://dx.doi.org/10.1080/0264206 $\underline{0500100833}$

[11] R. Garcia and R. Calantone, "A critical look at technological innovation typology and innovativeness terminology: a literature review," J Prod Innov Manag, Vol. 19(2), pp. 110132, 2002. https://doi.org/10.1111/1540-5885.1920110

[12] J. S. C. Lin and P. L. Hsieh, "The role of technology readiness in customers' perception and adoption of self-service technologies," Int J Serv Ind Mgnt, Vol. 17(5), pp. 497-517, 2006. https://doi.org/10.1108/09564230610689795

[13] A. Parasuraman, "Technology Readiness Index (TRI) a multiple-item scale to measure readiness to embrace new technologies," J Sev Res, Vol. 2(4), pp. 307-320, 2000. https://doi.org/10.1177/109467050024001

[14] D. G. Mick and S. Fournier, "Paradoxes of technology: Consumer cognizance, emotions, and coping strategies," J Consum Res, Vol. 25(2), pp. 123-143, 1998. https://doi.org/10.1086/209531

[15] V. Liljander et al., "Technology readiness and the evaluation and adoption of self-service technologies,” J Retail Consum Serv, Vol. 13(3), pp. 177-191, 2006. https://doi.org/10.1016/j.jretconser.2005.08.004

[16] J. S. C. Lin and H. C. Chang, "The role of technology readiness in self-service technology acceptance," Manag Serv Qua: Int J, Vol. 21(4), pp.424-444, 2011. https://doi.org/10.1108/09604521111146289

[17] Y. J. Joo et al., "Investigating the structural relationship among perceived innovation attributes, intention to use and actual use of mobile learning in an online university in South Korea," Aust J Edu Tech, Vol. 30(4), pp. 427-439, 2014. https://www.learntechlib.org/ $\mathrm{p} / 148493 /$

[18] Y. H. Lee et al., "Adding innovation diffusion theory to the technology acceptance model: Supporting employees' intentions to use e-learning systems," J Edu Techno Soc, Vol. 14(4), pp. 124-137, 2011. http://www.jstor.org/stable/jeductechsoci.14.4.124

[19] Y. H. Lee, "Exploring key factors that affect consumers to adopt e-reading services.," M.A. thesis, Huafan University, Taipei, Taiwan, 2007.

[20] R. T. Huang, "Exploring the Moderating Role of Self-Management of Learning in Mobile English Learning," Edu Techno Soc, Vol. 17(4), pp. 255-267, 2014. http://www.jstor.org/stable/jeductechsoci.17.4.255

[21] K. C. Yang, "Exploring factors affecting consumer intention to use mobile advertising in Taiwan,” J Int Consum Mark, Vol. 20(1), pp. 33-49, 2007. https://doi.org/10.1300/J046 v20n01 04

[22] M. Ally and J. Prieto-Blázquez, "What is the future of mobile learning in education?" Int J Edu Techno Edu, Vol. 11(1), pp. 142-151, 2014. https://doi.org/10.7238/rusc.v11i1.2033

[23] W. Shudong and M. Higgins, "Limitations of mobile phone learning. In Wireless and Mobile Technologies in Education," WMTE 2005. IEEE International Workshop on (pp. 3pp). IEEE, 2005, November. https://doi.org/10.1109/WMTE.2005.43

[24] D. Vogel et al., "Do mobile device applications affect learning? In System Sciences," HICSS 2007. 40th Annual Hawaii International Conference on (pp. 4-4). IEEE, 2007, January. https://doi.org/10.1109/HICSS.2007.181

[25] Y. Park, "A pedagogical framework for mobile learning: Categorizing educational applications of mobile technologies into four types," Int Rev Res Open Distrib Learn, Vol. 12(2), pp. 78-102, 2011. http://www.irrodl.org/index.php/irrodl/article/view/791/1699?utm sourc https://doi.org/10.19173/irrodl.v12i2.791 
[26] V. McKinney et al., "The measurement of web-customer satisfaction: An expectation and disconfirmation approach," Information systems research, Vol. 13(3), pp. 296-315, 2002. http://dx.doi.org/10.1287/isre.13.3.296.76 https://doi.org/10.1287/isre.13.3.296.76

[27] S. Pedersen, "Motivational orientation in a problem-based learning environment," J Interact Learn Res, Vol. 14(1), pp. 51-77, 2003. https://search.proquest.com/openview/835532f $\underline{8 \mathrm{dc} 1 \mathrm{~b} 131 \mathrm{flb} 2454 \mathrm{de} 25 \mathrm{da} 55 \mathrm{e} 1 / 1 \text { ?pq-origsite }=\text { gscholar\&cbl }=2031153}$

[28] C. Kulviwat, et al., "Self-efficacy as an antecedent of cognition and affect in technology acceptance," J Consum Mark, Vol. 31(3), pp. 190-199, 2014. https://doi.org/10.1108/JCM10-2013-0727

[29] C. P. Kao et al., "Development of a Survey to Measure Self-efficacy and Attitudes toward Web-based Professional Development among Elementary School Teachers," Edu Techno Soc, Vol. 17(4), pp. 302-315, 2014. http://www.jstor.org/stable/jeductechsoci.17.4.302

[30] F. Paraskeva et al., "Individual characteristics and computer self-efficacy in secondary education teachers to integrate technology in educational practice," Comput Educ, Vol. 50(3), pp. 1084-1091, 2008. https://doi.org/10.1016/j.compedu.2006.10.006

[31] S. Ram, "A model of innovation resistance," Adv Consum Res, Vol. 14, pp. 208-212, 1987. http://www.acrwebsite.org/search/view-conference-proceedings.aspx?Id=6688

[32] T. A. Judge et al., "Managerial coping with organizational change: A dispositional perspective," J Appl Psychol, Vol. 84(1), pp. 107-122, 1999. https://doi.org/10.1037/00219010.84.1.107

[33] S. Oreg, "Resistance to change: developing an individual differences measure," J Appl Psychol, Vol. 88(4), pp. 680-693, 2003. https://doi.org/10.1037/0021-9010.88.4.680

[34] C. Sanford and H. Oh, "The role of user resistance in the adoption of a mobile data service," Cyberpsychol Behav Soc Netw, Vol. 13(6), pp. 663-672, 2010. https://doi.org/10.1089/cyber.2009.0377

[35] W. Samuelson and R. Zeckhauser, "Status quo bias in decision making," J Risk Uncertain, Vol. 1(1), pp. 7-59, 1988. https://link.springer.com/article/10.1007/BF00055564, https://doi.org/10.1007/BF00055564

[36] P. Laukkanen et al., "Consumer resistance to internet banking: postponers, opponents and rejectors,” Int J Bank Mark, Vol. 26(6), pp. 440-455, 2008. https://doi.org/10.1108/0265 2320810902451

[37] K. Talke and S. Heidenreich, "How to overcome pro-change bias: incorporating passive and active innovation resistance in innovation decision models," J Prod Innov Manage, Vol. 31(5), pp. 894-907, 2014. https://doi.org/10.1111/jpim.12130

[38] C. Fornell and D.F. Larcker, "). Structural equation models with unobservable variables and measurement error: Algebra and statistics," J Mar Res, Vol.18(3), pp. 382-388, 1981. http://www.jstor.org/stable/3150980, https://doi.org/10.2307/3150980

[39] B.G. Tabachnik and L.S. Fidell, "Using multivariate statistics ( $5^{\text {th }}$ Edition)," Allyn \& Bacon, Inc. Needham Heights, MA, USA, 2006.

[40] J. Cohen, “A power primer," Psychol bull, Vol. 112(1), pp. 155-159, 1992. https://doi.org/10.1037/0033-2909.112.1.155

[41] A. Kukulska-Hulme et al., "Innovation in mobile learning: A European perspective," Int J Mob Blend Learn, Vol. 1(1), pp. 13-35, 2009. https://doi.org/10.4018/jmbl.2009010102

[42] M. L Meuter et al., "The influence of technology anxiety on consumer use and experiences with self-service technologies," J Bus Res Vol. 56(11), pp. 899-906, 2003. https://doi.org/10.1016/S0148-2963(01)00276-4

[43] R. Thakur et al., "Technological opinion leadership: The role of personal innovativeness, gadget love, and technological innovativeness," J Bus Res, Vol. 69(8), pp. 2764-2773, 2016. https://doi.org/10.1016/j.jbusres.2015.11.012 
[44] I. Milošević et al., "The effects of the intended behavior of students in the use of Mlearning," Comput Human Behav, Vol. 51, pp. 207-215, 2015. https://doi.org/10.1016/j.c hb.2015.04.041

[45] G. C. Moore and I. Benbasat, "Development of an instrument to measure the perceptions of adopting an information technology innovation. Inf Syst Res, Vol. 2(3), pp. 192-222, 1991. https://doi.org/10.1287/isre.2.3.192

[46] N. K. Malhotra et al., "Internet users' information privacy concerns (IUIPC): The construct, the scale, and a causal model," Inf Syst Res, Vol. 15(4), pp. 336-355, 2004. http://pubsonline.informs.org/doi/abs/10.1287/isre.1040.0032, https://doi.org/10.1287/isre. 1040.0032

[47] D. Kahneman et al., "Anomalies: The endowment effect, loss aversion, and status quo bias,” J Eco Perspect, Vol. 5(1), pp. 193-206, 1991. http://www.jstor.org/stable/1942711, https://doi.org/10.1257/jep.5.1.193

\section{Authors}

Hyo-Jung Kim is lecturer at the Department of Consumer Science, Seoul National University, Seoul, Republic of Korea.

Jong-Youn Rha is professor at the Department of Consumer Science, Seoul National University, Seoul, Republic of Korea.

Article submitted 11 September 2017. Published as resubmitted by the authors 17 November 2017. 